\title{
C Terminus of Presenilin Is Required for Overproduction of Amyloidogenic A $\beta 42$ through Stabilization and Endoproteolysis of Presenilin
}

\author{
Taisuke Tomita, ${ }^{1}$ Rie Takikawa, ${ }^{1}$ Akihiko Koyama, ${ }^{1}$ Yuichi Morohashi, ${ }^{1}$ Nobumasa Takasugi, ${ }^{1}$ \\ Takaomi C. Saido, ${ }^{2}$ Kei Maruyama, ${ }^{3}$ and Takeshi Iwatsubo \\ 1 Department of Neuropathology and Neuroscience, Graduate School of Pharmaceutical Sciences, University of Tokyo, \\ 7-3-1 Hongo Bunkyoku Tokyo 113-0033, Japan, 2Laboratory for Proteolytic Neuroscience, Brain Science Institute, \\ RIKEN, Wako, Saitama 351-0198, Japan, and 3Laboratory of Molecular Biology, Tokyo Institute of Psychiatry, \\ Kamikitazawa, Setagayaku, Tokyo 156-8585, Japan
}

Mutations in presenilin (PS) genes cause early onset familial Alzheimer's disease (FAD) by increasing production of the amyloidogenic form of amyloid $\beta$ peptides ending at residue 42 (A $\beta 42)$. To identify a PS subdomain responsible for overproduction of $A \beta 42$, we analyzed neuro2a cell lines expressing modified forms of PS2 that harbor an N141I FAD mutation. Deletion or addition of amino acids at the $C$ terminus and lle448 substitution in PS2 with the N141I FAD mutation abrogated the increase in $A \beta 42$ secretion, and $A \beta 42$ overproduction was de- pendent on the stabilization and endoproteolysis of PS2. The same C-terminal modifications in PS1 produced similar effects. Hence, we suggest that the $C$ terminus of PS plays a crucial role in the overproduction of $A \beta 42$ through stabilization of endoproteolytic PS derivatives and that these derivatives may be the pathologically active species of PS that cause FAD.

Key words: presenilin 2; presenilin 1; C terminus; amyloid $\beta$ peptide; $A \beta 42$; endoproteolysis; stabilization; familial Alzheimer's disease
Alzheimer's disease (AD) is characterized pathologically by a massive deposition of amyloid $\beta$ peptides $(\mathrm{A} \beta)$, which are proteolytically produced from $\beta$-amyloid precursor proteins ( $\beta$ APP) through two sequential cleavages by as yet unidentified proteases termed the $\beta$ - and $\gamma$-secretases (Selkoe, 1991, 1994). Two major forms of $\mathrm{A} \beta$ have distinct $\mathrm{C}$ termini ending at the 40th and 42nd residues ( $\mathrm{A} \beta 40$ and $\mathrm{A} \beta 42$, respectively), which are differentially cleaved by $\gamma$-secretase(s) (Suzuki et al., 1994). A $\beta 42$ aggregates much faster than A $\beta 40$ in vitro (Jarrett and Lansbury, 1993), and $\mathrm{A} \beta 42$ is the initially and predominantly deposited $\mathrm{A} \beta$ species in the brains of patients with AD and Down's syndrome (Iwatsubo et al., 1994, 1995). Moreover, missense mutations in $\beta$ APP genes, a rare cause of familial AD (FAD), lead to increased production of $A \beta 42$, strongly implicating $A \beta 42$ in the pathogenesis of $A D$ (Suzuki et al., 1994).

Presenilin (PS) 1 (Sherrington et al., 1995) and PS2 (LevyLahad et al., 1995) genes were identified as the major causative genes for early onset FAD that encode homologous polytopic membrane proteins spanning the membrane eight times (Doan et al., 1996; Li and Greenwald, 1998). Although a major proportion of nascent PS is rapidly degraded (Kim et al., 1997), a small

\footnotetext{
Received July 14, 1999; revised Sept. 10, 1999; accepted Sept. 29, 1999.

This work was supported by Grants-in-Aid from the Ministry of Health and Welfare, the Ministry of Education, Science, Culture and Sports, and CREST of Japan Science and Technology Corporation, Japan. We thank Drs. J. Q. Trojanowski for helpful comments on this manuscript, H. R. Kaback for valuable suggestions on the structure and stability of membrane proteins, Hiroshi Iwata for help in immunoprecipitation experiments, and Takeda Chemical Industries for continuous support.

Correspondence should be addressed to Dr. Takeshi Iwatsubo, Department of Neuropathology and Neuroscience, Graduate School of Pharmaceutical Sciences, University of Tokyo 7-3-1 Bunkyoku Hongo Tokyo 113-0033, Japan. E-mail: iwatsubo@mol.f.u-tokyo.ac.jp.

Copyright (C) 1999 Society for Neuroscience $0270-6474 / 99 / 1910627-08 \$ 05.00 / 0$
}

fraction of PS is stabilized and undergoes endoproteolysis, resulting in a heterodimeric complex of $\mathrm{N}$ - and $\mathrm{C}$-terminal derivatives (NTF and CTF, respectively) (Thinakaran et al., 1996; Capell et al., 1998) with an unusually long half-life (Thinakaran et al., 1996, 1997; Ratovitski et al., 1997). Overexpression of exogenous PS results in the replacement of endogenous PS fragments, suggesting that stabilization of PS is a saturable process competing for a limiting cellular factor (Thinakaran et al., 1996, 1997).

The finding that ablation of PS1 in mice dramatically decreased $\gamma$-cleavage of $\beta$ APP indicated that PS1 physiologically serves as a coactivator of $\gamma$-secretase (De Strooper et al., 1998). Moreover, data from studies in Caenorhabditis elegans (Levitan and Greenwald, 1995; Baumeister et al., 1997), PS1 knock-out mice (Shen et al., 1997; Wong et al., 1997; De Strooper et al., 1999), and Drosophila melanogaster (Song et al., 1999; Struhl and Greenwald, 1999; Ye et al., 1999) suggest that PS1 facilitates Notch signaling by activating a $\gamma$-secretase-like protease to release Notch intracellular domain (NICD), which activates transcription in nucleus.

More than 50 missense mutations in PS1, and two in PS2, have been identified in FAD pedigrees (Hardy, 1997). Accumulating data suggest that PS mutations cause AD by promoting the secretion of A $\beta 42$ (Borchelt et al., 1996; Duff et al., 1996; Citron et al., 1997; Tomita et al., 1997), although the mechanism whereby mutant (mt) PS leads to the increased production of $\mathrm{A} \beta 42$ remains unknown.

We recently reported that NTF of FAD mt PS2 alone cannot promote secretion of A $\beta 42$ (Tomita et al., 1998), and others showed that NTF of mt PS1 also does not enhance A $\beta 42$ production (Citron et al., 1998; Steiner et al., 1998). These data prompted us to postulate that a subdomain in the PS $\mathrm{C}$ terminus mediates $\mathrm{A} \beta 42$ overproduction and to undertake molecular dissection studies to identify this subdomain. 


\section{MATERIALS AND METHODS}

Construction of expression plasmids. A full-length cDNA encoding wildtype (wt) or N141I FAD mt human PS2 was obtained as described (Tomita et al., 1997, 1998). cDNAs encoding C-terminally modified wt or mt PS2 were generated by PCR using $P f u$ polymerase (Stratagene, La Jolla, CA), and the following oligonucleotides were used as PCR primers: 5'CCGGGATCCAGACCTCTCTGCGGCCCCAAG- ${ }^{\prime}$ as a sense primer, 5'-CCGGATCCCTACTTCTTGAACACAGC-3' for PS2/411stop, 5'CTGCTCGAGCTACAGGGTGTCCATGAA-3' for PS2/441stop, 5'CCGGAATTCTACTGATGGGAGGCCAG-3' for PS2/445stop, 5'-GGGCTCGAGTCAGATGTAGGCCTGATGGGA-3' for PS2/L446A, 5'-ACACCAGAATTCTCAGATGGCGAGCTGATGGGA-3' for PS2/ Y447A, 5'-ACACCAGAATTCTCAGGCGTAGAGCTGATGGGA-3' for PS2/I448A, 5'-CCGGAATTCTAGACGTAGAGCTGATGGGA-3' for PS2/I448V, 5'-CCGGAATTCTAGAAGTAGAGCTGATGGGA-3' for PS2/I448F, 5'-CCGGAATTCTACCTGTAGAGCTGATGGGA-3' for PS2/I448R, 5'-CCCGGGAATTCTAATGGTGATGGTGATGATGGATGTAGAGCTGATGGGA for PS2/CHis and 5'-CCCGGGAATTCTATATATATAATTGGTGACTGATGTAGAGCTGATGGGA for PS2/CDup as antisense primers, respectively. cDNAs encoding $\mathrm{N}$-terminally truncated wt or mt PS2 were similarly generated by PCR using the following primers: 5'-GGCACTCGAGTGTAAAACTATACAACTGC as an antisense primer, 5'CCGGATCCACCATGTCGGCCGAGAGC-3' for PS2/dAS, and 5'CCGGGATCCATGGAGGAAGAGCTGA-3' for PS2/dN as sense primers, respectively. A full-length cDNA encoding wt human PS1 containing VRSQ motif was obtained by PCR from a normal human brain cDNA library, and the P267S PS1 mutation was introduced by the dU-template method as described previously (Tomita et al., 1997). cDNAs encoding C-terminally modified wt or $\mathrm{mt} \mathrm{PS1}$ were generated by PCR using the following primers: 5'-CCCAAGCTTGCCACCATGACAGAGTTACCT-3' as a sense primer, 5'-CCCGGGAATTCTATAATTGGTCCATAAA-3' for PS1/460stop, and 5'-CCCGGGAATTCTAGCGATAAAATTGATG-3' for PS1/I467R as antisense primers, respectively. Schematic depictions of truncated and/or mutated PS derivatives are shown in Figure 1. All constructs were sequenced using Thermosequenase (Amersham, Arlington Heights, IL) on an automated sequencer (Li-Cor, Lincoln, NE) as described (Tomita et al., 1997, 1998).

Cell culture and transfection. Mouse neuro2a (N2a) cells were maintained in DMEM supplemented with $10 \%$ fetal calf serum and penicillin/ streptomycin at $37^{\circ} \mathrm{C}$ in $5 \% \mathrm{CO}_{2}$ atmosphere as described (Tomita et al., 1997, 1998). Stable N2a cell lines were generated by transfecting the cDNAs in pcDNA3 vector using Lipofectamine (Life Technologies, Gaithersburg, MD) and selection in DMEM containing G418 (Life Technologies) at $500 \mu \mathrm{g} / \mathrm{ml}$. Stable cell lines were analyzed at polyclonal stages unless otherwise stated.

Antibodies, immunoblot analysis, and cycloheximide treatment. The following rabbit polyclonal antibodies were used: anti-G2N2 against glutathione $S$-transferase (GST) fused to amino acids 2-84 of human PS2, anti-G2L against GST fused to amino acids 301-361 of human PS2, (Tomita et al., 1998), anti-PS1N against amino acids 1-22 of human PS1 (Tomita et al., 1997), and anti-G1L3 against GST fused to amino acids 297-379 of human PS1.

Cells were lysed in $2 \%$ SDS sample buffer and briefly sonicated. The samples were separated by SDS-PAGE without previous heating, transferred to polyvinylidene difluoride membrane (Millipore, Bedford, MA), and probed with each of the anti-PS antibodies as described (Tomita et al., 1997, 1998). The immunoblots were developed using an ECL system (Amersham)

To evaluate the half-lives of transfected PS proteins and fragments thereof by blocking total cellular protein synthesis, cultured cells were treated with cycloheximide $(30 \mu \mathrm{g} / \mathrm{ml})$ for $4,10,12$, or $24 \mathrm{hr}$ and then analyzed by immunoblotting with appropriate PS antibodies.

The capacity of transfected PS2 derivatives to replace endogenous PS1 was examined by immunoblotting cell lysates with anti-PS1N or antiG1L3 antibodies that react with both human and mouse PS1.

Quantitation of $A \beta$ by two-site ELISAs. Two-site ELISAs that specifically detect the $\mathrm{C}$ terminus of $\mathrm{A} \beta$ were used. BNT77, which was raised against human $\mathrm{A} \beta 11-28$ and recognizes full-length as well as N-terminally truncated $\mathrm{A} \beta$, was used as a capture antibody; BNT77 binds human as well as rodent-type $\mathrm{A} \beta$, but does not react with the $3 \mathrm{kDa}$ fragment (p3) beginning at the Leu-17 residue of $\mathrm{A} \beta$ (Fukumoto et al., 1999). BA27 and BC05, monoclonal antibodies that specifically recognize the $C$ termini of $A \beta 40$ and $A \beta 42$, respectively, were conjugated with horseradish peroxidase and used as detector antibodies. The specificity

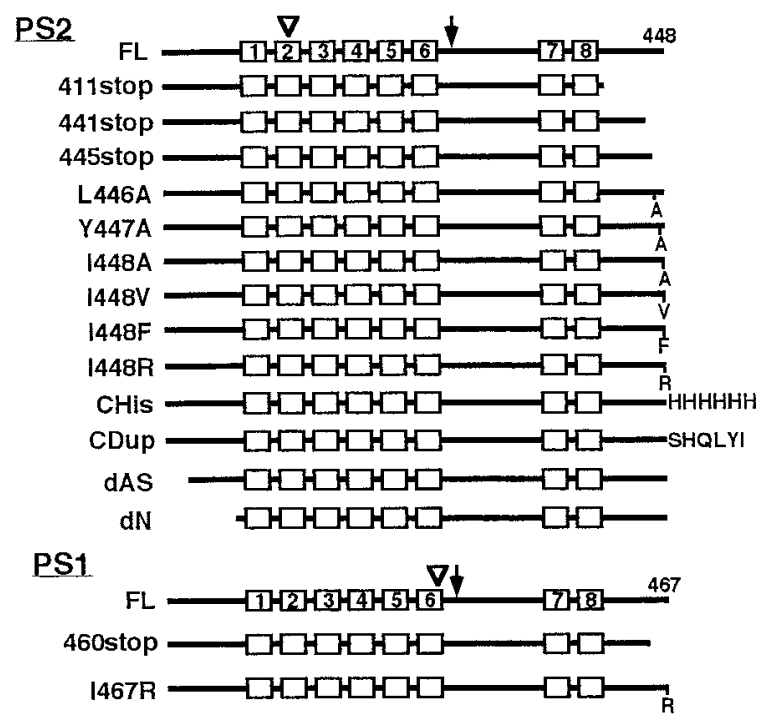

Figure 1. Schematic depictions of modified presenilins. Schematic representations of truncated or modified forms of PS2 (top) or PS1 (bottom) encoded by the cDNAs used in this study are shown. The names of cDNAs are indicated at the left of each bar, and squares with numbers represent putative TM domains. Open arrowheads on each bar show the location of amino acid substitutions linked to FAD (i.e., N141I in PS2 and P267S in PS1), and arrows between the TM 6 and 7 domains represent the sites of endoproteolytic processing. Amino acid substitution or addition at the C terminus of PS2 are shown below or at the right side of each bar, respectively.

and sensitivity of these ELISAs have been characterized previously (Asami-Odaka et al., 1995). Culture media were collected after an incubation period of $24 \mathrm{hr}$ and subjected to BNT77/BA27 or BC05 ELISAs as described (Tomita et al., 1997, 1998). Four independent measurements in duplicate were performed for each clone.

Quantitation of $A \beta$ by immunoprecipitation. Quantitation of $\mathrm{A} \beta$ by immunoprecipitation was performed according to the previously described method (Sudoh et al., 1998), with some modifications. Briefly, confluent N2a cells stably expressing PS2 or its derivatives were cultured in DMEM containing fetal bovine serum for $36 \mathrm{hr}$. Conditioned media (4.5 ml) were incubated with $2 \mu \mathrm{g}$ of BNT77, $5 \mu \mathrm{l}$ of goat $\mathrm{IgG}$ against mouse IgG, IgA, and IgM (Cappel, West Chester, PA), and $100 \mu \mathrm{l}$ of $25 \%$ protein $\mathrm{G}$ agarose (Life Technologies) at $4^{\circ} \mathrm{C}$ for $12 \mathrm{hr}$ on a rotary shaker. The immunoprecipitates were spun down, boiled in $2 \%$ SDS sample buffer, separated by SDS-PAGE on a $16.5 \%$ Tris/Tricine gel, and then blotted to a Hybond-ECL membrane filter (Amersham). After boiling in PBS, the membrane was probed with BA27 or BC05 $(8 \mu \mathrm{g} / \mathrm{ml}$, respectively) and then detected by the ECL system as described above.

\section{RESULTS}

\section{A small deletion at the $\mathrm{C}$ terminus of $\mathrm{mt}$ PS2 abrogates increased secretion of $A \beta 42$}

We previously showed that C-terminally truncated PS2 harboring the N141I FAD mutation (mt PS2) corresponding to endoproteolytic NTF (terminating at amino acid residue 303; 303stop), or retaining the entire sixth loop but truncated at the putative seventh transmembrane (TM) domain (388stop), lost the capacity to increase secretion of $\mathrm{A} \beta 42$ by N2a cells stably overexpressing these proteins (Tomita et al., 1998). To define the minimal PS2 $\mathrm{C}$-terminal region required for the overproduction of $\mathrm{A} \beta 42$, we constructed cDNAs encoding mt PS2 (full-length, 448 residues) with the following $\mathrm{C}$-terminal deletions ending at residues 411 (PS2/411stop), 441 (PS2/441stop), or 445 (PS2/445 stop) as shown in Figure 1. Stably transfected N2a cells expressing these constructs were examined to measure the secretion of $\mathrm{A} \beta 42$ by $\mathrm{A} \beta$ C-terminal-specific ELISAs. The percentage $\mathrm{A} \beta 42(\% \mathrm{~A} \beta 42)$ as a 


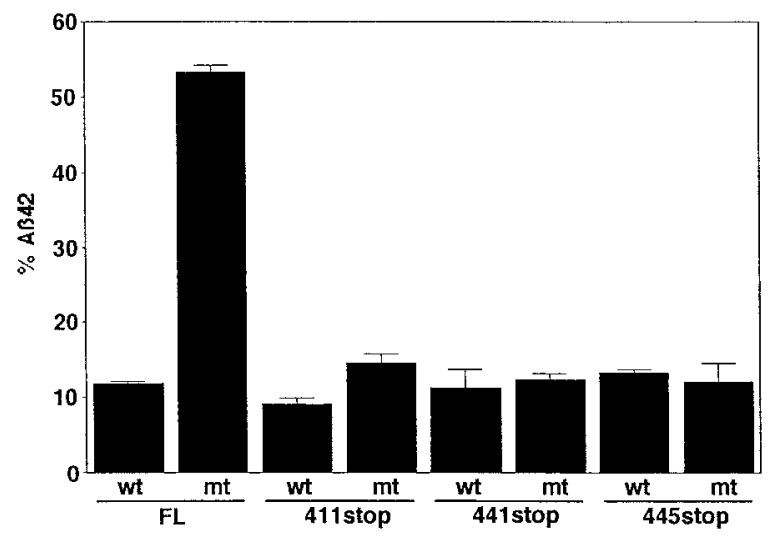

Figure 2. Percentages of $\mathrm{A} \beta 42$ secreted from cells expressing $\mathrm{C}$-terminally truncated PS2. Percentages of $\mathrm{A} \beta \mathrm{x}-42$ as a fraction of total $\mathrm{A} \beta(=\mathrm{A} \beta \mathrm{x}-40+\mathrm{A} \beta \mathrm{x}-42)(\% \mathrm{~A} \beta 42)$ secreted from $\mathrm{N} 2 \mathrm{a}$ cells stably transfected with full-length $(F L)$ or C-terminally truncated (411stop, 441stop, and 445stop) PS2 genes with $(m t)$ or without (wt) N141I FAD mutation quantitated by two-site ELISAs. Mean values \pm SE in four independent experiments are shown. Transfected PS2 cDNAs are indicated below the columns.

fraction of total $\mathrm{A} \beta(=\mathrm{A} \beta \mathrm{x}-40+\mathrm{A} \beta \mathrm{x}-42)$ secreted by cells stably expressing mt PS2/411stop, PS2/441stop or PS2/445stop was $\sim 10 \%$, and this was similar to the $\% \mathrm{~A} \beta 42$ secreted by cells expressing full-length (FL), wt PS2 or wt PS2/411stop, PS2/ 441stop, or PS2/445stop, whereas the $\% \mathrm{~A} \beta 42$ secreted from cells expressing FL mt PS2 was constantly elevated to $\sim 35-55 \%$ as previously documented (Tomita et al., 1997, 1998) (Fig. 2). The total amounts of secreted $\mathrm{A} \beta$ from cells transfected with these C-terminally truncated PS2 as determined by ELISA were comparable to those with FL PS2 (data not shown).

\section{Effects of substitution of the C-terminal residues of $\mathrm{mt}$ PS2 on $A \beta 42$ production}

Because truncation of three amino acid residues at the $\mathrm{C}$ terminus of mt PS2 [i.e., Leu (L) 446, Tyr (Y) 447, and Ile (I) 448] completely inhibited the increase in secretion of $\mathrm{A} \beta 42$, we next replaced each of these single residues with Ala and examined their effects on $\mathrm{A} \beta 42$ secreted by N2a cells, to determine whether one or more of these three residues critically affect the production of A $\beta 42$. mt PS2/L446A and PS2/Y447A increased the $\% \mathrm{~A} \beta 42$ to comparable levels seen in N2a cells with FL mt PS2 ( $\sim 5-55 \%)$, whereas $\% \mathrm{~A} \beta 42$ from cells expressing mt PS2/I448A was $\sim 25 \%$, which was at an intermediate level between those detected in the N2a cells with FL wt and mt PS2 (Fig. $3 A$ ).

We then focused on the role of residue I448, which is unusually hydrophobic for a $\mathrm{C}$-terminal residue oriented at the cytoplasmic side, on $\mathrm{A} \beta 42$ secretion and examined the effects that resulted from replacing this residue with amino acids having different properties, i.e., Val (V), which is similarly hydrophobic but has a slightly shorter carbon chain, Phe (F), which also is hydrophobic but harbors an aromatic ring, or Arg (R), which is hydrophilic with positive charges. $\mathrm{mt} \mathrm{PS} 2 / \mathrm{I} 448 \mathrm{~V}$ and $\mathrm{PS} 2 / \mathrm{I} 448 \mathrm{~F}$ enhanced secretion of $\mathrm{A} \beta 42$ from $\mathrm{N} 2 \mathrm{a}$ cells at comparable levels to those in $\mathrm{N} 2 \mathrm{a}$ cells expressing FL mt PS2. In sharp contrast, \%A $\beta 42$ secreted from cells expressing mt PS2/I448R was $\sim 10 \%$, which was similar to levels in cells with wt PS2 (Fig. $3 B$ ).

We further examined the secretion of $\mathrm{A} \beta 40$ and $\mathrm{A} \beta 42$ from cells transfected with these C-terminally substituted PS2 by immunoprecipitation with BNT77 and immunoblotting with BA27 and BC05, respectively (Fig. 3C). In N2a cells expressing FL wt
A

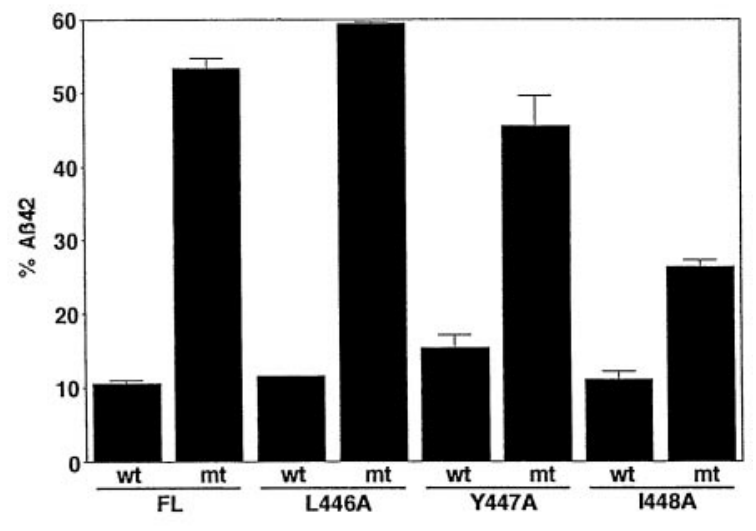

B
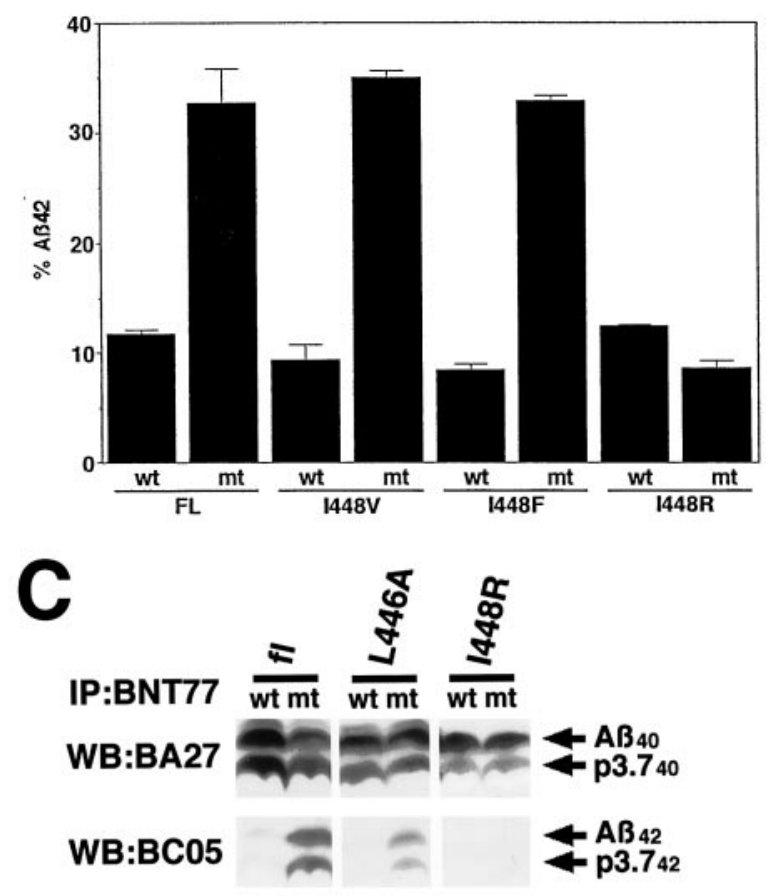

Figure 3. Percentages of A $\beta 42$ secreted from cells expressing PS2 with amino acid substitutions at the $\mathrm{C}$ terminus. $A, B$, Percentages of $\mathrm{A} \beta \mathrm{x}-42$ as a fraction of total $\mathrm{A} \beta(=\mathrm{A} \beta \mathrm{x}-40+\mathrm{A} \beta \mathrm{x}-42)(\% \mathrm{~A} \beta 42)$ secreted from $\mathrm{N} 2 \mathrm{a}$ cells stably transfected with PS2 genes with Ala substitution at Leu446 (L446A), Tyr447 (Y447A), or Ile448 (I448A) $(A)$ or substitution at Ile448 to Val $(I 448 V)$, Phe $(I 448 F)$, or $\operatorname{Arg}(I 448 R)(B)$ with $(m t)$ or without $(w t)$ N141I FAD mutation quantitated by two-site ELISAs. FL, Full-length PS2 without amino acid substitution at the $C$ terminus. Mean values $\pm \mathrm{SE}$ in four independent experiments are shown. Transfected PS2 cDNAs are indicated below the columns. $C$, Immunoprecipitation of the $4 \mathrm{kDa} A \beta_{40}$ and $\mathrm{A} \beta_{42}$ (arrows) as well as the $3.7 \mathrm{kDa}$ p3. $7_{40}$ and $\mathrm{p} 3.7_{42}$ (arrows) from conditioned media of N2a cells stably expressing wt or mt FL PS2 $(f l)$, PS2/L446A, or PS2/I448R by BNT77. Immunoprecipitates were visualized by Western blotting with BA27 or BC05.

PS2, robust $4 \mathrm{kDa}$ (Fig. $3 C, A \beta_{40}$ ), and $3.7 \mathrm{kDa}$ (Fig. $3 C, p 3.7_{40}$ ) bands immunoreactive with BA27 were observed, whereas BC05 detected only a trace amount of 4 and $3.7 \mathrm{kDa} A \beta$ peptides. In N2a cells expressing FL mt PS2, the intensities of the BA27- 


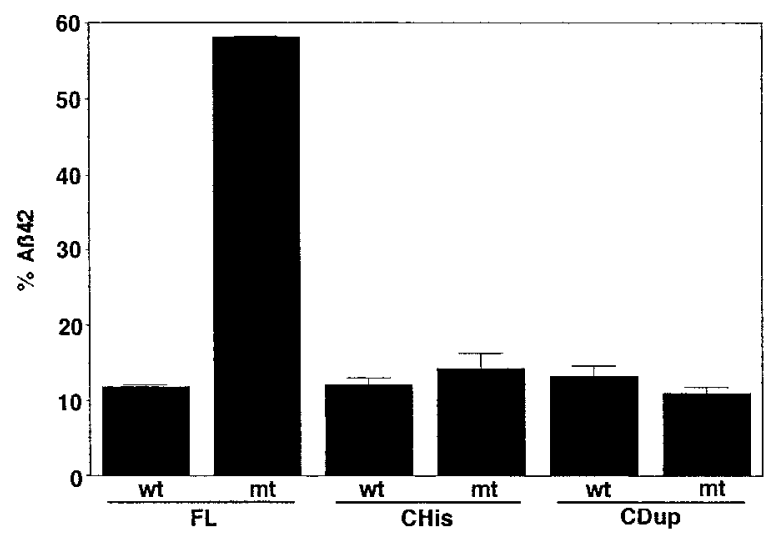

Figure 4. Percentages of $\mathrm{A} \beta 42$ secreted from cells expressing PS2 with addition of amino acids at the $\mathrm{C}$ terminus. Percentages of $\mathrm{A} \beta \mathrm{x}-42$ as a fraction of total $\mathrm{A} \beta(=\mathrm{A} \beta \mathrm{x}-40+\mathrm{A} \beta \mathrm{x}-42)(\% \mathrm{~A} \beta 42)$ secreted from $\mathrm{N} 2 \mathrm{a}$ cells stably transfected with PS2 genes with additional amino acids at the $\mathrm{C}$ terminus (CHis, six His residues; CDup, duplication of the C-terminal six amino acid residues of PS2) with $(m t)$ or without ( $w t$ ) N141I FAD mutation quantitated by two-site ELISAs. FL, Full-length PS2. Mean values \pm SE in four independent experiments are shown. Transfected PS2 cDNAs are indicated below the columns.

positive bands were weaker compared with those in cells expressing wt PS2, whereas stronger BC05-positive $4 \mathrm{kDa}$ (Fig. $3 C, A \beta_{42}$ ) and $3.7 \mathrm{kDa}$ (Fig. $3 C, p 3.7_{42}$ ) bands were observed. The amounts of the BC05-positive bands were similarly increased in $\mathrm{N} 2 \mathrm{a}$ cells expressing mt PS2/L446A, whereas no increase in the amount of BC05-positive bands was observed in cells expressing mt PS2/ I448R. These data were in agreement with those obtained by ELISA, suggesting that the levels as well as ratios of $A \beta 40$ and A $\beta 42$ as determined by ELISA correctly represent those of bona fide $\mathrm{A} \beta$ peptides (the $4 \mathrm{kDa}$ peptides may correspond to fulllength $\mathrm{A} \beta$ and the $3.7 \mathrm{kDa}$ peptides to $\mathrm{N}$-terminally truncated $\mathrm{A} \beta$, respectively). The total amounts of secreted $\mathrm{A} \beta$ from cells transfected with these C-terminally substituted PS2 as determined by ELISA also were at levels similar to those with wt PS2 (data not shown).

\section{Addition of amino acids to the PS2 C terminus abolishes increased $\mathbf{A} \boldsymbol{\beta} 42$ secretion}

We next examined the effects of the addition of amino acid residues to the $\mathrm{C}$ terminus of $\mathrm{mt}$ PS 2 on $\mathrm{A} \beta 42$ secretion. To this end, we used two different types of six amino acid long sequences: one contained six His residues (designated $\mathrm{CHis}$ ), which is often used as an epitope tag, and the other was Ser-His-Gln-Leu-TyrIle (designated CDup), which was identical to the last six amino acid residues of PS2. The latter was designed to determine whether the effect of mt PS2 on A $\beta 42$ secretion is dependent on the integrity of the $\mathrm{C}$-terminal amino acid sequences, regardless of the length of the $\mathrm{C}$ terminus. When stably transfected into $\mathrm{N} 2 \mathrm{a}$ cells, neither mt PS2/CHis nor mt PS2/CDup retained the capacity to increase secretion of $\mathrm{A} \beta 42$, and the $\% \mathrm{~A} \beta 42$ was $\sim 10 \%$, which was similar to cells with wt PS2 (Fig. 4). The total amounts of secreted $\mathrm{A} \beta$ from cells transfected with PS2 with additional residues at the $\mathrm{C}$ terminus again were comparable to those with FL PS2 (data not shown).

\section{Relationship between overproduction of $A \beta 42$ and stabilization and endoproteolysis of PS2}

It has not been definitively proven whether nascent holoproteins or stable complexes of endoproteolytic fragments (composed of
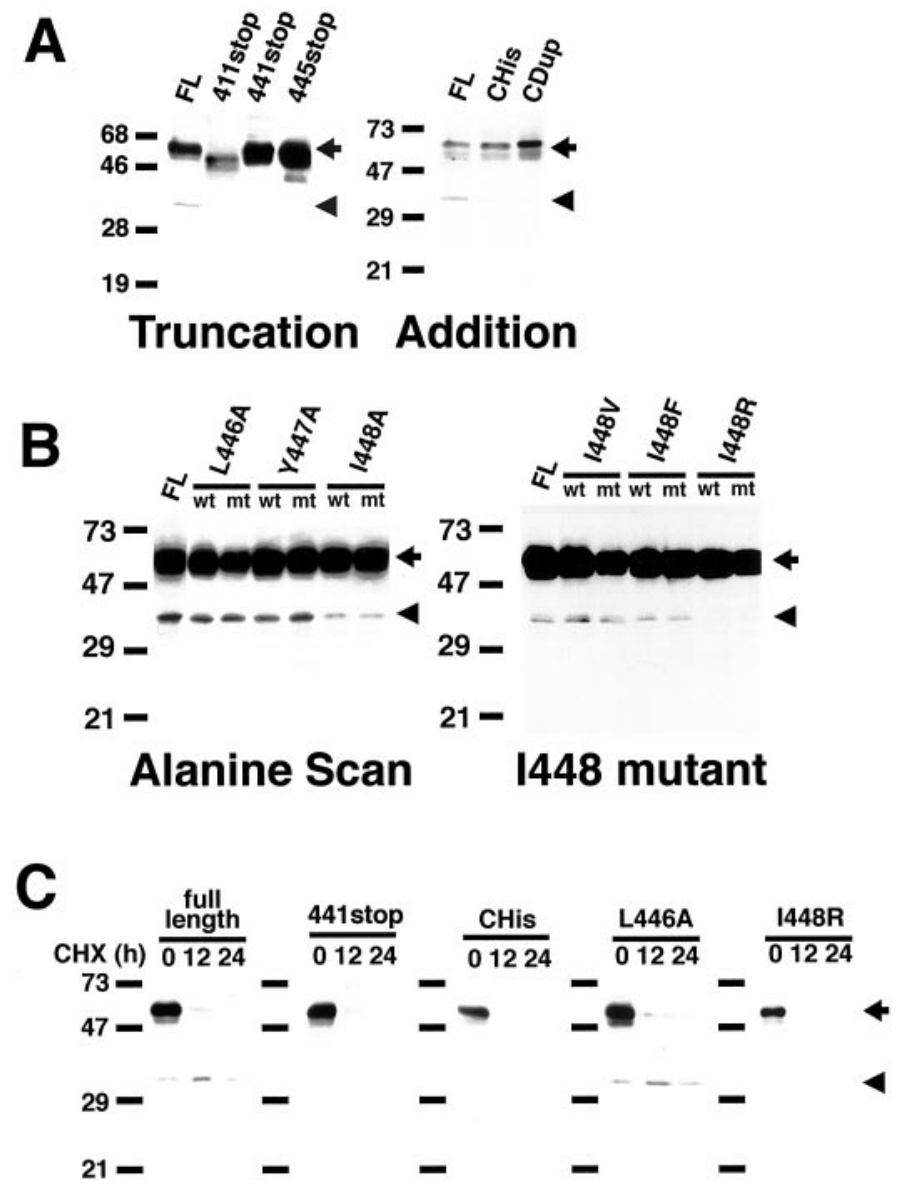

Figure 5. Expression, metabolism, and half-lives of PS2 derivatives in N2a stable cell lines. Western blot analysis of expression of PS2 with $\mathrm{C}$-terminal truncation $(A$, left panel $)$, addition $(A$, right panel $)$, single amino acid substitution to Ala ( $B$, left panel), or substitution at Ile448 (B, right panel) in stably transfected N2a cells. Cell lysates (20 $\mu \mathrm{g}$ protein) from N2a cells transfected with cDNAs encoding full-length $(F L)$ or modified PS2 were fractionated by SDS-PAGE and analyzed by immunoblotting with anti-G2N2 antibodies. PS2 cDNAs in $A$ are on a wild-type basis, but similar results were obtained in N141I FAD mt PS2 (data not shown). The names of the transfected cDNA constructs are indicated at the top of each lane. $C$, Analysis of the half-lives of PS2 derivatives. Cells were grown in the presence of cycloheximide $(C H X, 30 \mu \mathrm{g} / \mathrm{ml})$ for 0,12 , or $24 \mathrm{hr}$ and then harvested and analyzed as in $A$ and $B$. The positions of FL PS2 and endoproteolytic NTF are marked by arrows and arrowheads, respectively. Molecular mass standards are shown in kilodaltons.

NTF and CTF) of PS are the biologically active forms of these proteins. To investigate the relationship between stabilization and endoproteolysis of the C-terminally modified forms of PS2 studied here and their pathological overproduction of $\mathrm{A} \beta 42$, we analyzed the expression and metabolism of these proteins in $\mathrm{N} 2 \mathrm{a}$ stable cells by Western blots combined with cycloheximide treatment. All of the C-terminally truncated (i.e., PS2/411stop, PS2/ 441stop, or PS2/445stop) as well as tagged (i.e., PS2/CHis or PS2/CDup) PS2 that lacked the capacity to promote overproduction of $\mathrm{A} \beta 42$ also did not undergo endoproteolysis to give rise to $\mathrm{a} \sim 35 \mathrm{kDa}$ NTF and a $\sim 23 \mathrm{kDa}$ CTF normally produced from FL PS2 (Fig. $5 A$, arrowheads), although abundant holoproteins of corresponding sizes were expressed (Fig. $5 A$, arrows). With respect to $\mathrm{mt}$ PS2 with $\mathrm{C}$-terminal single amino acid substitution, mt PS2/L446A, PS2/Y447A, PS2/I448V, or PS2/I448F, which promoted $\mathrm{A} \beta 42$ secretion, were cleaved to form endoproteolytic 
A

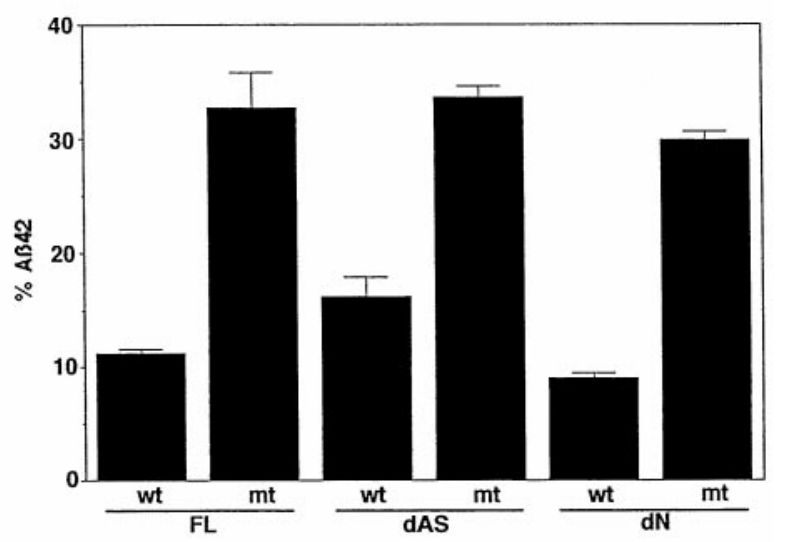

B

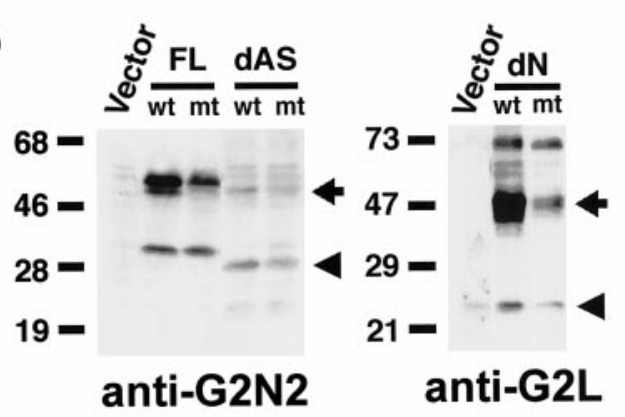

C
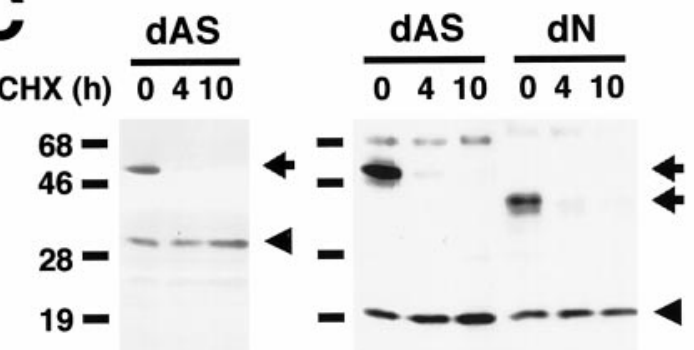

anti-G2N2 anti-G2L

Figure 6. Secretion of A $\beta 42$ and metabolism and stability of PS2 derivatives in cells expressing $\mathrm{N}$-terminally truncated PS2. $A$, Percentages of $\mathrm{A} \beta \mathrm{x}-42$ as a fraction of total $\mathrm{A} \beta(=\mathrm{A} \beta \mathrm{x}-40+\mathrm{A} \beta \mathrm{x}-42)(\% \mathrm{~A} \beta 42)$ secreted from N2a cells stably transfected with N-terminally truncated PS2 genes with $(m t)$ or without $(w t)$ N141I FAD mutation $(m t)$ quantitated by two-site ELISAs. $F L$, Full-length PS2; $d A S$, PS2 lacking the N-terminal acidic stretch corresponding to residues $1-20 ; d N$, PS2 lacking the entire $\mathrm{N}$-terminal cytoplasmic domain corresponding to residues 1-75. Mean values $\pm \mathrm{SE}$ in four independent experiments are shown. Transfected PS2 cDNAs are indicated below the columns. B, Western blot analysis of $\mathrm{N}$-terminally truncated PS2 in stably transfected N2a cells. Cell lysates (20 $\mu \mathrm{g}$ protein) from $\mathrm{N} 2 \mathrm{a}$ cells transfected with cDNAs encoding full-length $(F L)$ or N-terminally truncated PS2 were fractionated by SDS-PAGE and analyzed by immunoblotting with anti-G2N2 antibodies for dAS (left panel) and with anti-G2L for dN, which lacks the epitopes for anti-G2N2 (right panel). Note that correspondingly smaller holoproteins (arrows in both panels) and NTFs (arrowhead in the left panel) compared with those in cells with FL PS2 were detected and that transfection of $\mathrm{dN}$ gave rise to increased levels of CTF (arrowhead in $d N$; right panel) compared with those of endogenous CTF (arrowhead in Vector, right panel), indicating an effective generation of endoproteolytic fragments. Vector, Cells transfected with an empty pcDNA3 vector. $C$, Analysis of the half-lives of $\mathrm{N}$-terminally truncated PS2. Cells were grown in the presence of cycloheximide $(\mathrm{CHX})$ for 0,4 , or $10 \mathrm{hr}$ and then harvested and analyzed as in fragments, i.e., NTF (Fig. 5B, arrowheads) as well as CTF (data not shown), whereas mt PS2/I448R lacking this property was not cleaved (Fig. 5B, arrowheads). mt PS2/I448A, which showed intermediate levels of $\mathrm{A} \beta 42$ overproduction, yielded moderate levels of endoproteolytic fragments (Fig. $5 B$, left, arrowhead). Western blots after cycloheximide pretreatment revealed that holoproteins of C-terminally modified PS2 were short-lived with half-lives of $<12 \mathrm{hr}$ (Fig. 5C, arrow), whether endoproteolysis occurs or not. In contrast, the endoproteolytic fragments, if any, derived from transfected PS2 [e.g., NTF indicated by arrowhead in L446A of Fig. 5C, as well as corresponding CTF (data not shown)] acquired extraordinarily long half-lives of $>24 \mathrm{hr}$, as observed with fragments produced from FL PS2 (Fig. $5 C$ ). These results strongly suggest that the stable NTF/CTF complexes of mt PS are the pathologically active forms of PS that induce overproduction of $\mathrm{A} \beta 42$, and that the integrity of the $\mathrm{C}$-terminal structure of PS is critical for the stabilization of these complexes and the endoproteolysis of PS.

\section{$\mathbf{N}$ terminus of $\mathrm{mt} \mathrm{PS2}$ is dispensable for production of $A \beta 42$ as well as stabilization and endoproteolysis of PS2}

To gain insights into the role of the $\mathrm{N}$ terminus of PS2 in A $\beta 42$ production as well as on the stabilization and endoproteolysis of PS2, we constructed cDNAs encoding two types of N-terminally truncated PS2, i.e., dAS lacking the N-terminal 20 residues encompassing the acidic stretch, and $\mathrm{dN}$ lacking the entire N-terminal cytoplasmic domain corresponding to residues 1-75. When stably expressed in N2a cells, PS2/dAS as well as PS2/dN with N141I FAD mutation both increased the $\% \mathrm{~A} \beta 42$ at levels similar to that of cells with FL mt PS2 (Fig. 6A), although the total amounts of secreted $\mathrm{A} \beta$ were not altered (data not shown). Western blot analysis showed that both PS2/dAS and PS2/dN undergo endoproteolysis, yielding smaller NTFs and a $\sim 23 \mathrm{kDa}$ CTF of the same size as that derived from cells with FL PS2 (Fig. $6 B$ ). Cycloheximide treatment demonstrated that these endoproteolytic fragments have long half-lives ( $>10 \mathrm{hr}$ ) (Fig. 6C, arrowheads), whereas their corresponding holoproteins are short-lived (Fig. 6C, arrows). Taken together, we conclude that the $\mathrm{N}$ terminus of PS2 is dispensable for overproduction of $\mathrm{A} \beta 42$ as well as for stabilization and endoproteolysis of PS2.

\section{Replacement of endogenous PS1 by PS2 derivatives overexpressed in N2a cells}

To determine whether various types of PS2 derivatives overexpressed in N2a cells replace endogenous PS, we selected single clonal cell lines stably expressing $\mathrm{C}$ - or N-terminally modified PS2 and examined the levels of endogenous PS1 in representative clones (Fig. 7). The amounts of $\sim 30 \mathrm{kDa}$ NTF and $\sim 23 \mathrm{kDa}$ CTF of endogenous mouse PS1 were decreased in cells expressing FL wt or mt PS2, as well as in cells expressing PS2/1446A or PS2/dN, whereas they were maintained at levels similar to those in mock transfectants in cells expressing wt or mt PS2/445stop, PS2/I448R, or PS2/CHis. These results clearly showed that the pathologically active forms of mt PS2 that promote overproduction of $\mathrm{A} \beta 42$ can

\section{$\leftarrow$}

$B$. The positions of holoproteins of PS2/dAS or /dN are marked by arrows (both panels), and endoproteolytic NTF (left panel) and CTF (right panel) are marked by arrowheads, respectively. The names of the transfected cDNA constructs are indicated at the top of each lane. Molecular mass standards are shown in kilodaltons. 

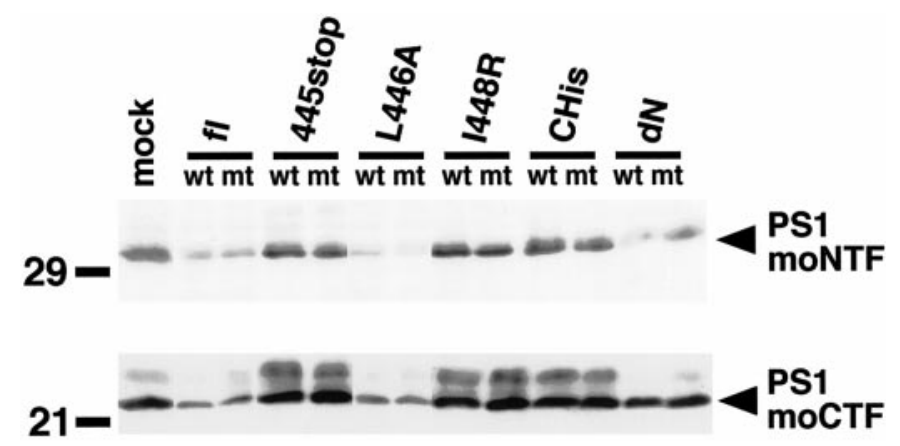

Figure 7. Replacement of endogenous PS1 by PS2 derivatives overexpressed in N2a cells. Western blot analysis of the levels of NTF (PS1 moNTF, top panel) and CTF (PS1 moCTF, bottom panel) of endogenous mouse PS1 in N2a cells stably transfected with C- or N-terminally modified PS2. Cell lysates ( $20 \mu \mathrm{g}$ protein) from N2a cells transfected with each cDNA were fractionated by SDS-PAGE and analyzed by immunoblotting with anti-PS1N (top panel) or anti-G1L3 (bottom panel) antibodies. The names of the transfected cDNA constructs are indicated at the top of each lane. mock, Cells transfected with an empty vector alone. Molecular mass standards are shown in kilodaltons.

replace endogenous PS, whereas replacement does not occur with $\mathrm{C}$-terminally modified PS2 lacking the A $\beta 42$-promoting effects.

\section{Integrity of the $\mathrm{C}$ terminus of $\mathrm{mt}$ PS1 is required for overproduction of $\mathrm{A} \boldsymbol{\beta} 42$}

To determine whether our conclusions regarding the role of PS C terminus are applicable to PS1, we constructed cDNAs encoding wt and Pro267Ser (P267S) mt PS1 lacking the last seven amino acid residues (PS1/460stop), and FL PS1 with the C-terminal residue Ile467 replaced by Arg (PS1/I467R), and stably expressed them in N2a cells. Consistent with the results obtained with PS2, FL P267S mt PS1 increased the $\% \mathrm{~A} \beta 42$ by $\sim 1.5$-fold compared with that of wt PS1, whereas the $\% \mathrm{~A} \beta 42$ was not elevated in cells with mt PS1/460stop nor with mt PS1/I467R (Fig. $8 A$ ), and the total amounts of secreted $\mathrm{A} \beta$ were not altered (data not shown). These C-terminally modified PS1 proteins were expressed as holoproteins (Fig. 8B, FL) but they were cleaved to produce only trace amounts of endoproteolytic fragments (Fig. $8 B, h u N T F$ ). These results confirmed that the integrity of the $C$-terminal structure of PS1 also is important for the overproduction of $\mathrm{A} \beta 42$ as well as for the stabilization and endoproteolysis of this protein similar to PS2.

\section{DISCUSSION}

In this study, we have clearly shown that (1) the integrity of the $\mathrm{C}$-terminal structure of PS is required for the ability of FAD $\mathrm{mt}$ PS to increase secretion of amyloidogenic A $\beta 42$; (2) subtle modifications of the $\mathrm{C}$ terminus of PS, especially those eliminating the hydrophobicity of the C-terminal Ile residue, abrogate the endoproteolysis of PS; (3) the pathological activity of FAD mt PS to increase $A \beta 42$ is most likely mediated by stabilized complexes of endoproteolytic fragments of PS; and (4) the N terminus of PS, in contrast to the $\mathrm{C}$ terminus, is dispensable for the overproduction of $\mathrm{A} \beta 42$, as well as for the stabilization or endoproteolysis of PS.

The mechanisms whereby PS proteins mediate their physiological as well as pathological functions remain elusive. Here we showed a strict parallel between the overproduction of $\mathrm{A} \beta 42$ and the stabilization and endoproteolysis of PS in a series of PS proteins harboring subtle modifications at the $\mathrm{C}$ terminus. Taken together with recent observations on PS1 (Steiner et al., 1998) or chimeric molecules of PS1NTF-PS2CTF (Saura et al., 1999), our

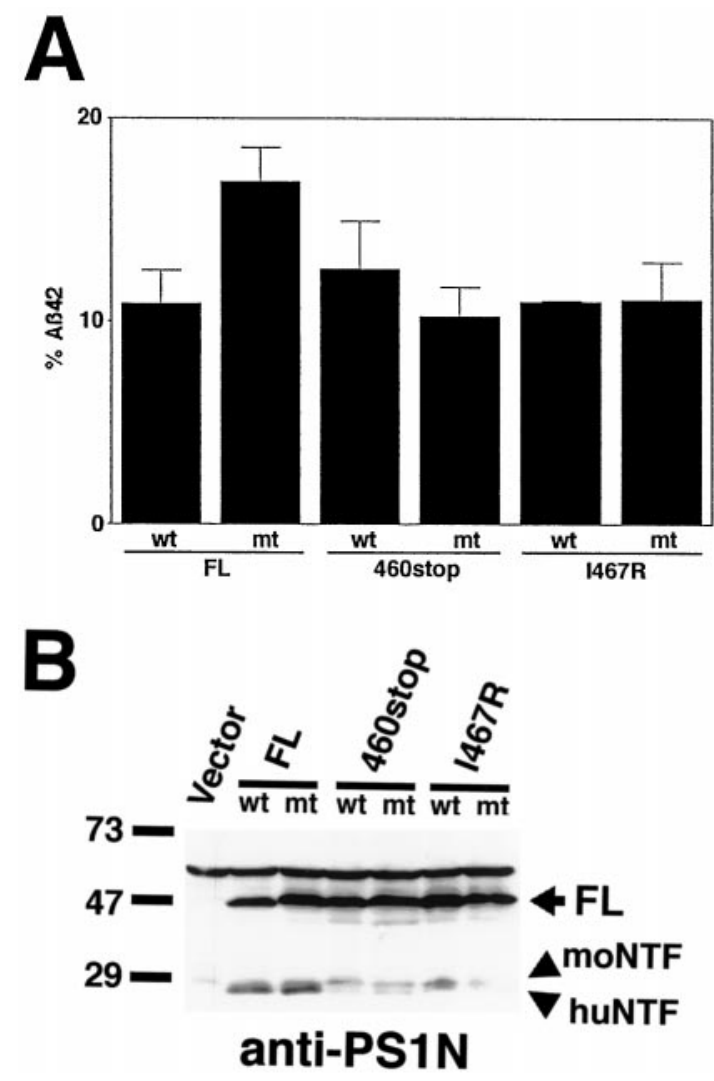

Figure 8. Secretion of A $\beta 42$ and metabolism of PS1 derivatives in cells expressing C-terminally modified PS1. $A$, Percentages of $\mathrm{A} \beta \mathrm{x}-42$ as a fraction of total $\mathrm{A} \beta(=\mathrm{A} \beta \mathrm{x}-40+\mathrm{A} \beta \mathrm{x}-42)(\% \mathrm{~A} \beta 42)$ secreted from $\mathrm{N} 2 \mathrm{a}$ cells stably transfected with cDNAs encoding full-length (FL) PS1, PS1 lacking the C-terminal 7 amino acid residues (460stop), or PS1 replaced at residue Ile467 with Arg (I467R) with $(m t)$ or without ( $w t)$ P267S FAD mutation quantitated by two-site ELISAs. Mean values \pm SE in four independent experiments are shown. Transfected PS1 cDNAs are indicated below the columns. $B$, Western blot analysis of C-terminally modified PS1 in stably transfected N2a cells. Cell lysates (20 $\mu$ g protein) from $\mathrm{N} 2 \mathrm{a}$ cells transfected with cDNAs encoding full-length $(F L)$, C-terminally truncated (460stop) or substituted (I467R) PS1 were fractionated by SDS-PAGE and analyzed by immunoblotting with anti-PS1N antibody. The approximate position of holoproteins is marked by arrow $(F L)$, and endogenous murine NTF ( $m o N T F$ ) and human NTF (huNTF) derived from transfected PS1 with a slightly faster mobility are marked by arrowheads, respectively. The names of the transfected cDNA constructs are indicated at the top of each lane. Molecular mass standards are shown in kilodaltons.

data support the notion that stabilized fragments of mt PS are responsible for the pathological augumentation of $\mathrm{A} \beta 42$ production, although the precise role of endoproteolytic cleavage in PS function remains unknown. FAD-associated mt PS1 lacking exon 9, which escapes cleavage within the sixth loop domain, is stabilized (Ratovitski et al., 1997), incorporated into high molecular weight stable complexes (Capell et al., 1998), and acquires the abnormal ability to promote overproduction of $\mathrm{A} \beta 42$ caused by an amino acid substitution at the splice junction site (Steiner et al., 1999), suggesting that endoproteolysis merely represents a molecular signature that indicates the occurrence of stabilization but is not mandatory for the function of PS.

Very recently, it was reported that mutating either of the two conserved Asp residues in the sixth and seventh TM domains of PS1 substantially reduces $\gamma$-cleavage of $\beta$ APP as well as PS1 endoproteolysis, whereas these Asp-mutated PS1 species can 
replace endogenous PS1 fragments, thereby eliminating the activity of PS1 in cells (Wolfe et al., 1999). It is conceivable that the two Asp residues are essential for the ability of PS1 to activate (or alternatively, to work as a) $\gamma$-secretase that is mediated by the stabilized form of PS, whereas the C terminus of PS plays a critical role in the formation of the stabilized complexes of PS, which in turn leads to increased secretion and deposition of $\mathrm{A} \beta 42$ in the FAD brains and cells. In this regard, it is particularly interesting that some of the loss-of-function SEL-12 mutants in C. elegans (Levitan and Greenwald, 1995) or Drosophila PS mutants (Struhl and Greenwald, 1999), which are incapable of facilitating Notch signaling, are truncated at the $\mathrm{C}$ terminus (e.g., within the putative seventh loop domain in the ar133 mutant of SEL-12) (Levitan and Greenwald, 1995). Further studies will be needed to determine whether these C-terminally truncated PS homologs are stabilized, and whether stabilized complex of PS is required for $\gamma$ (-like) cleavage of Notch or $\beta$ APP to release NICD or $\mathrm{A} \beta$, respectively.

What then is the mechanistic role of the PS C terminus in the stabilization and function of PS proteins? Holoproteins of C-terminally modified PS polypeptides studied here were robustly expressed, and as we have previously confirmed with NTFs of PS2, they were inserted into membranes and localized to endoplasmic reticulum [Tomita et al. (1998) and our unpublished observations], despite their relatively short half-lives. One possible mechanism would be that the highly hydrophobic cytoplasmic tails of PS (i.e., -Leu-Tyr-Ile for PS2 and -Phe-Tyr-Ile for PS1) serve as the binding domain of some interacting proteins that are required for the stabilization of PS. Notably, PDZ domaincontaining proteins are known to bind to the $\mathrm{C}$ terminus of transmembrane proteins with specific motifs such as Ser/Thr-XVal/Ile (for group I PDZ domains) or hydrophobic amino acids at positions -2 and 0 (for group II) (Songyang et al., 1997), the latter being very similar to those of the PS C terminus noted above. In fact, deletion, mutation, or addition of C-terminal amino acid residues abolishes their binding to PDZ domains (Saras et al., 1997). Taken together with the fact that the stabilization of PS is regulated by competition for limiting cellular factor(s), it is tempting to speculate that interacting proteins that bind to the $\mathrm{C}$ terminus of PS are the determinants for the stabilization and replacement of PS that are vital to the function of PS.

Another possibility would be that the $C$ terminus of PS per se plays an important role in the proper folding or conformation of PS required for the stabilization and/or function of PS proteins. Although little is known about the roles of different domains of polytopic membrane proteins in the stabilization of polypeptides, data from deletion studies in lac permease of Escherichia coli may have interesting implications for our findings. Lac permease is a polytopic membrane protein that spans the membrane 12 times, with the $\mathrm{N}$ and $\mathrm{C}$ termini oriented to the cytoplasmic side. Kaback and colleagues (Roepe et al., 1989) have shown that a total ablation of the 17 amino acid C-terminal cytoplasmic tail of lac permease does not have any decremental effects on the stabilization and function of this protein, whereas additional deletion of five more amino acids constituting the $\mathrm{C}$-terminal portion of the 12th TM domain drastically destabilized the protein after insertion into the membrane. It was also reported that removal of the C-terminal tails of two other polytopic membrane proteins, bacteriorhodopsin (Huang et al., 1981) or melibiose permease (Botfield and Wilson, 1989), did not affect their functions. Thus, it is highly likely that the $\mathrm{C}$ terminus of PS, especially the hydrophobic $\mathrm{C}$-terminal residues, plays a unique role in the stabiliza- tion of PS as a polytopic membrane protein. The precise mechanism whereby the $\mathrm{C}$ terminus stabilizes PS is unknown at present; it may bind to some important domain within the TM or loop structures of PS to maintain a structure required for stabilization or function, or alternatively, the hydrophobic $\mathrm{C}$ terminus may interact with, or is anchored within, membranes ensuring the proper conformation of PS. It is also possible that the conformation of the whole protein maintained by the $\mathrm{C}$ terminus allows the binding of a limiting factor (protein) with some portion(s) of PS outside the $\mathrm{C}$ terminus.

The hydrophobic $\mathrm{C}$ terminus of PS could be a therapeutic target for the treatment of FAD because the development of small compounds that bind to the $\mathrm{C}$ terminus of PS and mimic these modifications may destabilize and reduce the total amount of "functional" mt PS proteins, which promote overproduction of $\mathrm{A} \beta 42$, in the brains of patients with FAD linked to PS mutations. Future studies of the roles of the $\mathrm{C}$ terminus of PS will pave the way for understanding the pathomechanisms as well as for the development of novel therapeutic strategies for FAD and possibly sporadic AD.

\section{REFERENCES}

Asami-Odaka A, Ishibashi Y, Kikuchi T, Kitada C, Suzuki N (1995) Long amyloid $\beta$-protein secreted from wild-type human neuroblastoma IMR-32 cells. Biochemistry 34:10272-10278.

Baumeister R, Leimer U, Zweckbronner I, Jakubek C, Grünberg J, Haass C (1997) Human presenilin-1, but not familial Alzheimer's disease (FAD) mutants, facilitate Caenorhabditis elegans Notch signalling independently of proteolytic processing. Genes Function 1:149-159.

Borchelt DR, Thinakaran G, Eckman CB, Lee MK, Davenport F, Ratovitsky T, Prada CM, Kim G, Seekins S, Yager D, Slunt HH, Wang R, Seeger M, Levey AI, Gandy SE, Copeland NG, Jenkins NA, Price DL, Younkin SG, Sisodia SS (1996) Familial Alzheimer's disease-linked presenilin 1 variants elevate $A \beta 1-42 / 1-40$ ratio in vitro and in vivo. Neuron 17:1005-1013.

Botfield MC, Wilson TH (1989) Carboxyl-terminal truncations of the melibiose carrier of Escherichia coli. J Biol Chem 264:11643-11648.

Capell A, Grünberg J, Pesold B, Diehlmann A, Citron M, Nixon R, Beyreuther K, Selkoe DJ, Haass C (1998) The proteolytic fragments of the Alzheimer's disease-associated presenilin-1 form heterodimers and occur as a $100-150-\mathrm{kDa}$ molecular mass complex. J Biol Chem 273:3205-3211.

Citron M, Westaway D, Xia W, Carlson G, Diehl T, Levesque G, Johnson-Wood K, Lee M, Seubert P, Davis A, Kholodenko D, Motter R, Sherrington R, Perry B, Yao H, Strome R, Lieberburg I, Rommens J, Kim S, Schenk D, Fraser P, St. George-Hyslop P, Selkoe DJ (1997) Mutant presenilins of Alzheimer's disease increase production of 42residue amyloid $\beta$-protein in both transfected cells and transgenic mice. Nat Med 3:67-72.

Citron M, Eckman CB, Diehl TS, Corcoran C, Ostaszewski BL, Xia W, Levesque G, St. George-Hyslop P, Younkin SG, Selkoe DJ (1998) Additive effects of PS1 and APP mutations on secretion of the 42residue amyloid $\beta$-protein. Neurobiol Dis 5:107-116.

De Strooper B, Saftig P, Craessaerts K, Vanderstichele H, Guhde G, Annaert W, Von Figura K, Van Leuven F (1998) Deficiency of presenilin-1 inhibits the normal cleavage of amyloid precursor protein. Nature 391:387-390.

De Strooper B, Annaert W, Cupers P, Saftig P, Craessaerts K, Mumm JS, Schroeter EH, Schrijvers V, Wolfe MS, Ray WJ, Goate A, Kopan R (1999) A presenilin-1-dependent $\gamma$-secretase-like protease mediates release of Notch intracellular domain. Nature 398:518-522.

Doan A, Thinakaran G, Borchelt DR, Slunt HH, Ratovitsky T, Podlisny M, Selkoe DJ, Seegar M, Gandy SE, Price DL, Sisodia SS (1996) Protein topology of presenilin 1. Neuron 17:1023-1030.

Duff K, Eckman C, Zehr C, Yu X, Prada C-M, Perez-tur J, Hutton M, Buee L, Harigaya Y, Yager D, Morgan D, Gordon MN, Holcomb L, Refolo L, Zenk B, Hardy J, Younkin S (1996) Increased amyloid$\beta 42(43)$ in brains of mice expressing mutant presenilin 1 . Nature 383:710-713.

Fukumoto H, Tomita T, Matsunaga H, Ishibashi Y, Saido TC, Iwatsubo T (1999) Primary cultures of neuronal and non-neuronal rat brain cells 
secrete similar proportions of amyloid $\beta$ peptides ending at $\mathrm{A} \beta 40$ and A $\beta 42$. NeuroReport 10:2965-2969.

Hardy J (1997) The Alzheimer family of diseases: many etiologies, one pathogenesis? Proc Natl Acad Sci USA 94:2095-2097.

Huang KS, Bayley H, Liao MJ, London E, Khorana HG (1981) Refolding of an integral membrane protein. Denaturation, renaturation, and reconstitution of intact bacteriorhodopsin and two proteolytic fragments. J Biol Chem 256:3802-3809.

Iwatsubo T, Odaka A, Suzuki N, Mizusawa H, Nukina N, Ihara Y (1994) Visualization of $A \beta 42(43)$ and $A \beta 40$ in senile plaques with end-specific A $\beta$ monoclonals: evidence that an initially deposited species is A $\beta 42(43)$. Neuron 13:45-53.

Iwatsubo T, Mann DMA, Odaka A, Suzuki N, Ihara Y (1995) Amyloid $\beta$ protein $(\mathrm{A} \beta)$ deposition: $\mathrm{A} \beta 42(43)$ precedes $\mathrm{A} \beta 40$ in Down syndrome. Ann Neurol 37:294-299.

Jarrett JT, Lansbury Jr PT (1993) Seeding "one-dimensional crystallization" of amyloid: a pathogenic mechanism in Alzheimer's disease and scrapie? Cell 73:1055-1058.

Kim TW, Pettingell WH, Hallmark OG, Moir RD, Wasco W, Tanzi RE (1997) Endoproteolytic cleavage and proteasomal degradation of presenilin 2 in transfected cells. J Biol Chem 272:11006-11010.

Levitan D, Greenwald I (1995) Facilitation of lin-12-mediated signalling by sel-12, a Caenorhabditis elegans S182 Alzheimer's disease gene. Nature 377:351-354.

Levy-Lahad E, Wasco W, Poorkaj P, Romano DM, Oshima J, Pettingell WH, Yu C-E, Jondro PD, Schmidt SD, Wang K, Crowley AC, Fu Y-H, Guenette SY, Galas D, Nemens E, Wijsman EM, Bird TD, Schellenberg GD, Tanzi RE (1995) Candidate gene for the chromosome 1 familial Alzheimer's disease locus. Science 269:973-977.

Li X, Greenwald I (1998) Additional evidence for an eighttransmembrane-domain topology for Caenorhabditis elegans and human presenilins. Proc Natl Acad Sci USA 95:7109-7114.

Ratovitski T, Slunt HH, Thinakaran G, Price DL, Sisodia SS, Borchelt DR (1997) Endoproteolytic processing and stabilization of wild-type and mutant presenilin. J Biol Chem 272:24536-24541.

Roepe PD, Zbar RI, Sarkar HK, Kaback HR (1989) A five-residue sequence near the carboxyl terminus of the polytopic membrane protein lac permease is required for stability within the membrane. Proc Natl Acad Sci USA 86:3992-3996.

Saras J, Engstrom U, Gonez LJ, Heldin CH (1997) Characterization of the interactions between PDZ domains of the protein-tyrosine phosphatase PTPL1 and the carboxyl-terminal tail of Fas. J Biol Chem 272:20979-20981.

Saura CA, Tomita T, Davenport F, Harris CL, Iwatsubo T, Thinakaran G (1999) Evidence that intramolecular associations between presenilin domains are obligatory for endoproteolytic processing. J Biol Chem 274:13818-13823.

Selkoe DJ (1991) The molecular pathology of Alzheimer's disease. Neuron 6:487-498.

Selkoe DJ (1994) Cell biology of the amyloid $\beta$-protein precursor and the mechanism of Alzheimer's disease. Annu Rev Cell Biol 10:373-403.

Shen J, Bronson RT, Chen DF, Xia W, Selkoe DJ, Tonegawa S (1997) Skeletal and CNS defects in presenilin-1-deficient mice. Cell 89:629-639.

Sherrington R, Rogaev EI, Liang Y, Rogaeva EA, Levesque G, Ikeda M, Chi H, Lin C, Li G, Holman K, Tsuda T, Mar L, Foncin J-F, Bruni AC, Montesi MP, Sorbi S, Rainero I, Pinessi L, Nee L, Chumakov I, Pollen D, Brookes A, Sanseau P, Polinsky RJ, Wasco W, Da Silva HAR, Haines JL, Pericak-Vance MA, Tanzi RE, Roses AD, Fraser PE, Rommens JM, St. George-Hyslop PH (1995) Cloning of a gene bear- ing missense mutations in early-onset familial Alzheimer's disease. Nature 375:754-760.

Song W, Nadeau P, Yuan M, Yang X, Shen J, Yankner BA (1999) Proteolytic release and nuclear translocation of notch-1 are induced by presenilin-1 and impaired by pathogenic presenilin-1 mutations. Proc Natl Acad Sci USA 96:6959-6963.

Songyang Z, Fanning AS, Fu C, Xu J, Marfatia SM, Chishti AH, Crompton A, Chan AC, Anderson JM, Cantley LC (1997) Recognition of unique carboxyl-terminal motifs by distinct PDZ domains. Science 275:73-77.

Steiner H, Capell A, Pesold B, Citron M, Kloetzel PM, Selkoe DJ, Romig H, Mendla K, Haass C (1998) Expression of Alzheimer's disease-associated presenilin-1 is controlled by proteolytic degradation and complex formation. J Biol Chem 273:32322-32331.

Steiner H, Romig H, Grim MG, Philipp U, Pesold B, Citron M, Baumeister R, Haass C (1999) The biological and pathological function of the presenilin-1 $\Delta$ exon 9 mutation is independent of its defect to undergo proteolytic processing. J Biol Chem 274:7615-7618.

Struhl G, Greenwald I (1999) Presenilin is required for activity and nuclear access of Notch in Drosophila. Nature 398:522-525.

Sudoh S, Kawamura Y, Sato S, Wang R, Saido TC, Oyama F, Sakaki Y, Komano H, Yanagisawa K (1998) Presenilin 1 mutations linked to familial Alzheimer's disease increase the intracellular levels of amyloid $\beta$-protein 1-42 and its $\mathrm{N}$-terminally truncated variant(s) which are generated at distinct sites. J Neurochem 71:1535-1543.

Suzuki N, Cheung TT, Cai X-D, Odaka A, Otvos Jr L, Eckman C, Golde TE, Younkin SG (1994) An increased percentage of long amyloid $\beta$-protein is secreted by familial amyloid $\beta$-protein precursor ( $\beta$ APP717) mutants. Science 264:1336-1340.

Thinakaran G, Borchelt DR, Lee MK, Slunt HH, Spitzer L, Kim G, Ratovitsky T, Davenport F, Nordstedt C, Seeger M, Hardy J, Levey AI, Gandy SE, Jenkins NA, Copeland NG, Price DL, Sisodia SS (1996) Endoproteolysis of presenilin 1 and accumulation of processed derivatives in vivo. Neuron 17:181-190.

Thinakaran G, Harris CL, Ratovitski T, Davenport F, Slunt HH, Price DL, Borchelt DR, Sisodia SS (1997) Evidence that levels of presenilins (PS1 and PS2) are coordinately regulated by competition for limiting cellular factors. J Biol Chem 272:28415-28422.

Tomita T, Maruyama K, Saido TC, Kume H, Shinozaki K, Tokuhiro S, Capell A, Walter J, Grünberg J, Haass C, Iwatsubo T, Obata K (1997) The presenilin 2 mutation (N141I) linked to familial Alzheimer disease (Volga German families) increases the secretion of amyloid $\beta$ protein ending at the 42nd (or 43rd) residue. Proc Natl Acad Sci USA 94:2025-2030.

Tomita T, Tokuhiro S, Hashimoto T, Aiba K, Saido TC, Maruyama K, Iwatsubo T (1998) Molecular dissection of domains in mutant presenilin 2 that mediate overproduction of amyloidogenic forms of amyloid $\beta$ peptides. Inability of truncated forms of PS2 with familial Alzheimer's disease mutation to increase secretion of $\mathrm{A} \beta 42$. J Biol Chem 273:21153-21160.

Wolfe MS, Xia W, Ostaszewski BL, Diehl TS, Kimberly WT, Selkoe DJ (1999) Two transmembrane aspartates in presenilin-1 required for presenilin endoproteolysis and $\gamma$-secretase activity. Nature 398:513-517.

Wong PC, Zheng H, Chen H, Becher MW, Sirinathsinghji DJ, Trumbauer ME, Chen HY, Price DL, Van der Ploeg LH, Sisodia SS (1997) Presenilin 1 is required for Notch1 and Dll1 expression in the paraxial mesoderm. Nature 387:288-292.

Ye Y, Lukinova N, Fortini ME (1999) Neurogenic phenotypes and altered Notch processing in Drosophila Presenilin mutants. Nature 398:525-529. 